\title{
Differentiation of Bacillus globisporus, Bacillus marinus comb. nov., Bacillus aminovorans, and Bacillus insolitus
}

\author{
H.-J. RÜGER
}

\author{
Institut für Meeresforschung, D-2850 Bremerhaven, Federal Republic of Germany
}

\begin{abstract}
The type strains of Bacillus globisporus subsp. globisporus and B. globisporus subsp. marinus were shown to have only $20 \%$ deoxyribonucleic acid homology. These two organisms could be differentiated by 15 physiological characteristics, including salt requirements, production of $\beta$-galactosidase, digestion of urea and esculin, fermentation of carbohydrates, and utilization of carbohydrates as sole carbon sources. Therefore, $B$. globisporus subsp. marinus is elevated to species rank as Bacillus marinus. The type strain of B. globisporus, strain ATCC 23301, and B. globisporus ATCC 23304 (ex "Bacillus psychrophilus" type strain) showed only $50 \%$ deoxyribonucleic acid homology, but these strains could not be differentiated phenotypically and are still considered members of the same species, B. globisporus. Deoxyribonucleic acid homology data and phenotypic properties confirmed that Bacillus aminovorans, Bacillus insolitus, B. globisporus, and B. marinus are separate species.
\end{abstract}

Bacillus globisporus subsp. marinus cells are able to grow at temperatures between 5 and $30^{\circ} \mathrm{C}$, but not at $37^{\circ} \mathrm{C}$. Optimal growth occurs between 12 and $23^{\circ} \mathrm{C}(14)$. Low growth temperatures have also been reported for some other bacilli that produce round endospores (i.e., $B a$ cillus aminovorans, Bacillus globisporus, and Bacillus insolitus) $(4,6)$. Strains of these psychrophilic, round-spored Bacillus species gave similar results in some standard identification tests $(4,14)$ and thus are not easily distinguishable. Therefore, I attempted to differentiate $\boldsymbol{B}$. aminovorans, B. globisporus, B. globisporus subsp. marinus, and $B$. insolitus by conventional and Minitek identification procedures and by deoxyribonucleic acid (DNA)-DNA hybridization experiments.

\section{MATERIALS AND METHODS}

Bacterial strains. The following bacterial strains were used in this study: $B$. aminovorans NRS $341^{\mathrm{T}}$ (type strain), which was received from R. E. Gordon; B. globisporus subsp. globisporus DSM $4^{\mathrm{T}}$ (= ATCC 23301') and DSM 3 (=ATCC 23304; ex "B. psychrophilus" type strain), which were obtained from Deutsche Sammlung von Mikroorganismen (DSM), Göttingen, Federal Republic of Germany; B. globisporus subsp. marinus DSM $1297^{\mathrm{T}}\left(=\right.$ ATCC $\left.29841^{\mathrm{T}}\right)$ and DSM 1298 (= ATCC 29840), which were obtained from marine sediments (14); and $B$. insolitus DSM $5^{\mathrm{T}}$ $\left(=\right.$ ATCC $\left.23299^{\mathrm{T}}\right)$, which was received from Deutsche Sammlung von Mikroorganismen.

Biochemical characterization of strains. The methods described by Rüger and Richter (14) were used. The carbohydrate fermentation tests were performed with the Minitek identification system, but the growth media and conditions were modified as described previously (11). The method of Leifson (7) also was used to test fermentation of arabinose, fructose, glucose, glycerol, lactose, maltose, mannitol, sucrose, and xylose.

Utilization of carbohydrates as sole sources of carbon was determined in a minimal medium containing $2.0 \mathrm{~g}$ of $\mathrm{NH}_{4} \mathrm{Cl}, 2.0 \mathrm{~g}$ of $\mathrm{MgSO}_{4} \cdot 7 \mathrm{H}_{2} \mathrm{O}, 0.05 \mathrm{~g}$ of $\mathrm{K}_{2} \mathrm{HPO}_{4}, 0.5 \mathrm{~g}$ of $\mathrm{KNO}_{3}, 0.3 \mathrm{~g}$ of yeast extract, $500 \mathrm{ml}$

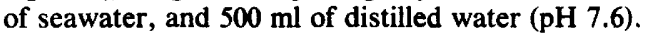

The carbohydrates were added to the medium as Minitek substrate-saturated paper disks. The test tubes were inoculated with $0.1 \mathrm{ml}$ of inoculum grown at $18^{\circ} \mathrm{C}$ for $24 \mathrm{~h}$ in modified ZoBell type 2216 seawater broth containing $5 \mathrm{~g}$ of peptone, $1 \mathrm{~g}$ of yeast extract, $0.01 \mathrm{~g}$ of $\mathrm{FePO}_{4} \cdot 4 \mathrm{H}_{2} \mathrm{O}, 750 \mathrm{ml}$ of seawater, and 250 $\mathrm{ml}$ of distilled water (pH 7.6). Cell density was measured at $650 \mathrm{~nm}$ with a Gilford model 250 spectrophotometer immediately after inoculation and after $2,4,7$, and 11 days of incubation at $18^{\circ} \mathrm{C}$. A wavelength of 650 $\mathrm{nm}$ was chosen because phenol red was used as the indicator in the test papers. Inoculated minimal media without the addition of carbohydrate were used as controls.

Guanine-plus-cytosine content and DNA hybridization. DNA was isolated by the method of Marmur (8) from cells grown as previously described (14). The melting temperature of the DNA was determined by the method of Marmur and Doty (9) with a Gilford model 250 spectrophotometer equipped with a Gilford model 2527 thermoprogrammer. The guanine-plus-cytosine content of the DNA was calculated from the melting temperature by using the equation given by $\mathrm{De}$ Ley (2). DNA from Escherichia coli $\mathrm{K}-12$ was used as a standard. The DNA base ratio for each strain was calculated from nine test results.

DNA hybridization was determined from renaturation rates, as described by De Ley et al. (3). The DNA used for hybridization experiments was isolated by the method of Marmur (8), dialyzed against $2 \times$ standard saline citrate buffer $(1 \times$ standard saline citrate is $0.15 \mathrm{M} \mathrm{NaCl}$ plus $0.015 \mathrm{M}$ sodium citrate), and 
sheared by passage through a French pressure cell (catalog no. 4-3399; Aminco, Silver Spring, Md.) at 1,100 bars. The renaturation experiments were performed in a Gilford thermocuvette. The denaturation temperature was adjusted to $93^{\circ} \mathrm{C}$ and maintained for 30 min after the maximal hyperchromicity had been achieved; then the temperature was rapidly adjusted to $61^{\circ} \mathrm{C}$. The change in absorbance, which reached linearity after a few minutes, was recorded for $40 \mathrm{~min}$. Renaturation rates were determined directly from the renaturation curves in the time intervals between 6 and $36 \mathrm{~min}$ and between 8 and $36 \mathrm{~min}$ after the samples were cooled. The degrees of DNA-DNA binding were calculated from the renaturation rates by using equation 20 of De Ley et al. (3). Five renaturation experiments were performed for each combination of strains.

\section{RESULTS}

All strains were gram positive, peritrichous, and strictly aerobic, and they produced catalase and grew well at $5^{\circ} \mathrm{C}$.

None of the strains grew at $37^{\circ} \mathrm{C}$ or gave a positive result in the methyl red test or the
Voges-Proskauer reaction. They did not produce indole, pigments, lipase, arginine dihydrolase, lysine decarboxylase, or ornithine decarboxylase or ferment adonitol, arabinose, cellobiose, dulcitol, galactose, inositol, mannitol, melibiose, rhamnose, salicin, or sorbitol. The strains tested were not able to utilize arabinose, chitin, citrate, dulcitol, esculin, fructose, galactose, inositol, lactose, malonate, mannitol, mannose, melibiose, raffinose, rhamnose, salicin, or sorbitol as a sole carbon source.

The characters which are useful for differentiating among the strains of $B$. aminovorans, $B$. globisporus, $B$. marinus, and $B$. insolitus are listed in Table 1.

The identification tests giving variable results for 18 strains of $B$. globisporus subsp. marinus described by Rüger and Richter (14) were not taken into consideration for differentiating the psychrophilic, round-spored bacilli. These tests or characteristics were: growth at $30^{\circ} \mathrm{C}$; production of oxidase, indophenol oxidase, and ammo-

TABLE 1. Characteristics that differentiate psychrophilic, round-spored Bacillus species

\begin{tabular}{|c|c|c|c|c|c|c|}
\hline \multirow[b]{2}{*}{ Characteristic } & \multicolumn{2}{|c|}{ B. globisporus } & \multicolumn{2}{|c|}{ B. marinus } & \multirow{2}{*}{$\begin{array}{l}\text { B. aminovorans } \\
\text { NRS } 341^{\mathrm{T}}\end{array}$} & \multirow{2}{*}{$\begin{array}{l}\text { B. insolitus } \\
\text { DSM } 5^{\mathrm{T}}\end{array}$} \\
\hline & $\operatorname{DSM} 4^{T}$ & $\begin{array}{l}\text { DSM } 3 \text { (ex "B. } \\
\text { psychrophilus") }\end{array}$ & $\operatorname{DSM} 1297^{\top}$ & DSM 1298 & & \\
\hline $\begin{array}{l}\text { Guanine-plus-cytosine } \\
\text { content of DNA }\end{array}$ & $40.6 \pm 0.6^{b}$ & $39.7 \pm 0.3^{b}$ & $39.3 \pm 0.5^{b}$ & $39.5 \pm 0.9^{b}$ & $40.3 \pm 0.5$ & $35.6 \pm 0.2$ \\
\hline $\begin{array}{l}\text { Spores swell the spo- } \\
\text { rangium }\end{array}$ & $+^{c}$ & + & - & - & - & - \\
\hline Growth without $\mathrm{Na}^{+}$ & $t^{d}$ & $t^{d}$ & $-^{d}$ & $-d$ & + & + \\
\hline Growth without $\mathrm{K}^{+}$ & $+^{d}$ & $t^{d}$ & $-d$ & $-d$ & ND & ND \\
\hline Digestion of urea & + & + & - & - & + & - \\
\hline $\begin{array}{l}\text { Production of } \beta \text {-galac- } \\
\text { tosidase }\end{array}$ & + & + & - & - & - & - \\
\hline $\begin{array}{l}\text { Hydrolysis of esculin } \\
\text { Fermentation of: }\end{array}$ & - & - & + & + & - & - \\
\hline Glucose & - & - & + & + & + & - \\
\hline Fructose & - & - & + & + & - & - \\
\hline Maltose & - & - & $\mathbf{v}$ & $\mathbf{v}$ & + & - \\
\hline Mannose & - & - & + & + & - & - \\
\hline Raffinose & - & - & - & - & + & + \\
\hline Sucrose & - & - & $\mathbf{v}$ & $\mathbf{v}$ & - & - \\
\hline Trehalose & - & - & + & + & + & - \\
\hline \multicolumn{7}{|l|}{$\begin{array}{l}\text { Utilization as sole car- } \\
\text { bon source }\end{array}$} \\
\hline Adonitol & - & + & - & - & - & - \\
\hline Cellobiose & - & - & + & + & - & - \\
\hline Glucose & - & + & - & - & + & - \\
\hline Glycerol & + & + & - & - & - & - \\
\hline Maltose & - & - & - & - & + & - \\
\hline Sucrose & - & - & - & - & + & - \\
\hline Trehalose & - & - & + & + & + & - \\
\hline Xylose & - & + & + & - & - & - \\
\hline
\end{tabular}

${ }^{a}$ Expressed as moles percent.

$b$ Data from reference 14 .

$c+$, Positive; - negative; $v$, positive results were obtained with conventional methods, but negative results were obtained with the Minitek system; ND, not determined.

${ }^{d}$ Data from reference 12 .

e $o$-Nitrophenyl- $\beta$-D-galactopyranoside test. 
nia from peptone; nitrate reduction; susceptibility to pteridin $0 / 129(10 \mu \mathrm{g})$, terramycin $(5 \mu \mathrm{g})$, and penicillin $\mathrm{G}(2 \mathrm{U})$; action on litmus milk; digestion of casein; and fermentation of glycerol, lactose, and xylose. When the Leifson method was used, B. globisporus (ex " B. psychrophilus") DSM 3 fermented xylose only after 28 days of incubation, but with the Minitek system this test gave negative results. Gordon et al. (4) reported positive results for this strain. Starch hydrolysis was not considered because my results for B. aminovorans NRS 341 and B. globisporus DSM 3 differed from those reported by Gordon et al. (4).

The DNA homology data are summarized in Table 2. The DNA homology value of $50 \%$ obtained for strains $B$. globisporus DSM 3 and DSM $4^{\mathrm{T}}$ was unexpectedly low. Therefore, these strains were checked for purity, and the homology experiments were repeated with newly isolated DNAs. The first experiments with these strains gave values of $51.0 \pm 3.4 \%$, and the second tests revealed $50.1 \pm 1.7 \%$ DNA homology. The marine strains had $95 \%$ DNA homology, and for the other strain combinations the homologies ranged from 20 to $39 \%$.

\section{DISCUSSION}

The psychrophilic bacilli $B$. globisporus and " $B$. psychrophilus" described by Larkin and Stokes (6) could not be differentiated clearly solely on the basis of routine biochemical characteristics $(4,5,13)$. In addition, these two species have the same cell wall composition (13) and therefore were combined in one species, $B$. globisporus $(13,15)$. Although the term psychrophilic is generally applied to maximal bacterial growth at temperatures below $20^{\circ} \mathrm{C}(10)$, it should be stated that strains of these species originally called psychrophilic $(5,6)$ are also able to grow at $30^{\circ} \mathrm{C}$.

DNA homology values of only $50 \%$, as found here when the type strain of $B$. globisporus and the former type strain of " $B$. psychrophilus" were compared, are too low for bacteria of the same species (1). However, only 3 of 85 characteristics were different in these two strains, namely, utilization of adonitol, glucose, and xylose (Table 1). Until it is established that these properties distinguish most or all homologous strains in the two species, these strains should be considered members of $B$. globisporus.

The differential characteristics presented in Table 1 and the DNA homology data of Table 2 confirm that $B$. aminovorans, $B$. insolitus, $B$. globisporus, and $B$. marinus are separate species.

Finding same cell wall composition in the strains tested was one of the reasons for combining "B. psychrophilus" with B. globisporus and for designating the marine bacilli subspecies of $B$. globisporus $(13,14)$. However, the data in Tables 1 and 2 indicate that this type of cell wall composition is not species specific.

The description of $B$. globisporus subsp. marinus Rüger and Richter 1979 (14) was based on morphological, physiological, and biochemical characteristics, including cell wall analyses. In the present study additional biochemical tests and DNA homology data were used to determine the relationship of $B$. globisporus to the other two psychrophilic, round-spored Bacillus species, $B$. aminovorans and $B$. insolitus. This study revealed that the marine strains should be separated from $B$. globisporus to form a distinct species, Bacillus marinus.

Bacillus marinus comb. nov. emend. The cells are gram-positive, straight rods with rounded ends and occur singly or in pairs. The average cell size is 0.9 to 1.2 by 2.0 to $4.0 \mu \mathrm{m}$ as determined by phase-contrast microscopy and 0.5 to 1.0 by 1.5 to $4.0 \mu \mathrm{m}$ in Gram-stained preparations. Filaments may be present.

The cells are motile and peritrichous.

Endospores are produced; these endospores are spherical, terminal or subterminal, and 0.8 to $1.0 \mu \mathrm{m}$ in diameter and do not swell the sporangium.

On seawater broth supplemented with $1.5 \%$ agar, colonies are circular with entire margins, flat to raised, smooth, translucent, nonpigment-

TABLE 2. DNA homologies among strains of psychrophilic, round-spored Bacillus species

\begin{tabular}{|c|c|c|c|c|c|c|}
\hline \multirow{3}{*}{ Strain } & \multicolumn{6}{|c|}{ \% DNA homology with: } \\
\hline & \multicolumn{2}{|c|}{ B. globisporus } & \multicolumn{2}{|c|}{ B. marinus } & \multirow{2}{*}{$\begin{array}{l}\text { B. aminovorans } \\
\text { NRS } 341^{\mathrm{T}}\end{array}$} & \multirow{2}{*}{$\begin{array}{l}\text { B. insolitus } \\
\text { DSM } 5^{\mathrm{T}}\end{array}$} \\
\hline & $\operatorname{DSM} 4^{\mathrm{T}}$ & $\begin{array}{l}\text { DSM } 3 \text { (ex "B. } \\
\text { psychrophilus") }\end{array}$ & DSM $1297^{\mathrm{T}}$ & DSM 1298 & & \\
\hline B. globisporus DSM $4^{\mathrm{T}}$ & 100 & & & & & \\
\hline $\begin{array}{l}\text { B. globisporus DSM } 3 \text { (ex } \\
\text { "B. psychrophilus") }\end{array}$ & 50 & 100 & & & & \\
\hline B. marinus DSM $1297^{T}$ & 20 & 24 & 100 & & & \\
\hline B. marinus DSM 1298 & 28 & 26 & 95 & 100 & & \\
\hline B. aminovorans NRS $341^{\mathrm{T}}$ & 26 & 31 & 36 & 39 & 100 & \\
\hline B. insolitus DSM $5^{\mathrm{T}}$ & 30 & 28 & 31 & 29 & 38 & 100 \\
\hline
\end{tabular}


ed, and 3 to $5 \mathrm{~mm}$ in diameter after 7 days at $20^{\circ} \mathrm{C}$. Two colony types with different transparencies were observed after freeze-dried or vacuum-dried cells were cultured (14).

Good growth in seawater broth with uniform turbidity and a colorless sediment after 4 days at $20^{\circ} \mathrm{C}$.

No growth in the absence of $\mathrm{NaCl}$. The concentrations of $\mathrm{NaCl}$ for optimal growth are between 3.0 and $3.5 \%$ for 11 strains, including the type strain, and between 1 and $3 \%$ for 7 strains (14). There is slight growth with $7 \% \mathrm{NaCl}(12$ strains), but not with $10 \% \mathrm{NaCl}$ (14).

No growth in the absence of $\mathrm{KCl}$. The optimal concentration for growth is between 2.5 and 5.0 $\mathrm{mM}$. Growth rates do not decrease at higher concentrations of $\mathrm{KCl}$ (up to $100 \mathrm{mM}$ ) (12).

Moderate to good growth at $5^{\circ} \mathrm{C}$ (one strain negative). Optimal growth at 12 to $23^{\circ} \mathrm{C}$. Of eighteen strains, 9, including the type strain, grow at $30^{\circ} \mathrm{C}(14)$. No growth occurs at $37^{\circ} \mathrm{C}$.

Strictly aerobic.

Catalase is produced. The Kovacs oxidase test gives positive or variable results with seven strains, including the type strain (14). Except for one strain, indophenol oxidase (cytochrome oxidase) is not produced (14).

The methyl red test is negative; acetylmethylcarbinol and indole are not produced.

Hydrogen sulfide is produced within 18 days. Ten strains, but not the type strain, produce ammonia from peptone (14).

The nitrate reduction test gives different results; 11 strains, including the type strain, are negative, and 7 strains reduce nitrate to nitrite (14).

No growth occurs in an inorganic nitrogen medium, and citrate is not used as a sole carbon source.

Casein is digested by 16 strains, including the type strain (14), and gelatin is liquefied within 3 days. Reactions in litmus milk are variable (14).

Urease, arginine dihydrolase, lysine decarboxylase, and ornithine decarboxylase are not produced.

Eleven strains (including the type strain) are susceptible to pteridin 0/129, five strains (including the type strain) are susceptible to terramycin, and 15 strains (including the type strain) are susceptible to penicillin G (14).

Starch, chitin, and alginate are not digested, and lipase is not produced.

Esculin is hydrolyzed. The $o$-nitrophenyl- $\beta$-Dgalactopyranoside test ( $\beta$-galactosidase production) is negative.

Acid but no gas is produced from glucose, fructose, maltose, mannose, sucrose, and trehalose. Acid is produced from glycerol by 7 strains (the type strain is positive), from lactose by 16 strains (the type strain is positive), and from xylose by 6 strains (the type strain is positive). With the method of Leifson (7), positive results occur after 2 to 40 days of incubation at $20^{\circ} \mathrm{C}$ (14), and with the Minitek system positive results occur after 1 to 4 days.

No acid is produced from adonitol, arabinose, cellobiose, dulcitol, galactose, inositol, mannitol, melibiose, raffinose, rhamnose, salicin, or sorbitol.

Cellobiose and trehalose are utilized as sole carbon sources by strains DSM $1297^{\mathrm{T}}$ and DSM 1298; xylose is utilized by strain DSM $1297^{\mathrm{T}}$. No growth is observed with adonitol, arabinose, dulcitol, esculin, fructose, galactose, glucose, glycerol, inositol, lactose, malonate, maltose, mannitol, melibiose, raffinose, rhamnose, salicin, sorbitol, or sucrose as the sole source of carbon.

Habitat: marine sediments.

The DNA composition of the type strain is $39.3 \pm 0.5 \mathrm{~mol} \%$ guanine plus cytosine, as determined by the melting temperature method.

The type strain of B. marinus is strain ATCC 29841 (= DSM 1297).

The description of $B$. marinus is based on 18 strains (14). Growth in the absence of $\mathrm{KCl}$ was tested with four strains, including the type strain (12). Tests performed only with strains DSM $1297^{\mathrm{T}}$ and DSM 1298 were hydrolysis of esculin, the $o$-nitrophenyl- $\beta$-D-galactopyranoside test, acid production from adonitol, cellobiose, dulcitol, galactose, inositol, mannose, melibiose, raffinose, rhamnose, salicin, sorbitol, and trehalose, and utilization of carbohydrates as sole sources of carbon.

\section{ACKNOWLEDGMENTS}

I am grateful to D. Claus for helpful discussions, and to Christa Summa and Uta Riethmüller for skillful technical assistance.

I thank the Deutsche Forschungsgemeinschaft for supporting this work.

\section{LITERATURE CITED}

1. De Ley, J. 1968. Molecular biology and bacterial phylogeny. Evol. Biol. 2:103-156.

2. De Ley, J. 1970. Reexamination of the association between melting point, buoyant density, and chemical base composition of deoxyribonucleic acid. J. Bacteriol. 101:738-754.

3. De Ley, J., H. Cattoir, and A. Reynaerts. 1970. The quantitative measurement of DNA hybridization from renaturation rates. Eur. J. Biochem. 12:133-142.

4. Gordon, R. E., W. C. Haynes, and C. H.-N. Pang. 1973. The genus Bacillus. Handbook 427. U.S. Department of Agriculture, Washington, D.C.

5. Gyllenberg, H. G., and J. J. Laine. 1971. Numerical approach to the taxonomy of psychrophilic bacilli. Ann. Med. Exp. Biol. Fenn. 49:62-66.

6. Larkin, J. M., and J. L. Stokes. 1967. Taxonomy of psychrophilic strains of Bacillus. J. Bacteriol. 94:889-895.

7. Leifson, E. 1963. Determination of carbohydrate metabolism of marine bacteria. J. Bacteriol. 85:1183-1184.

8. Marmur, J. 1961. A procedure for the isolation of deoxyri- 
bonucleic acid from micro-organisms. J. Mol. Biol. 3:208218.

9. Marmur, H., and P. Doty. 1962. Determination of the base composition of deoxyribonucleic acid from its thermal denaturation temperature. J. Mol. Biol. 5:109-118.

10. Morita, R. Y. 1975. Psychrophilic bacteria. Bacteriol. Rev. 39:144-167

11. Rüger, H.-J. 1981. Comparison of the API and Minitek identification systems with conventional methods for differentiating marine bacteria. Veröff. Inst. Meeresforsch. Bremerhaven 19:21-34.

12. Rüger, H.-J., and G. Hentasehel. 1980. Mineral salt re- quirements of Bacillus globisporus subsp. marinus strains. Arch. Microbiol. 126:83-86.

13. Rüger, H.-J., and G. Richter. 1979. Bacillus psychrophilus Larkin and Stokes 1967, a later subjective synonym of Bacillus globisporus Larkin and Stokes 1967. Int. J. Syst. Bacteriol. 29:194-195.

14. Rüger, H.-J., and G. Richter. 1979. Bacillus globisporus subsp. marinus subsp. nov. Int. J. Syst. Bacteriol. 29:196-203.

15. Skerman, V. B. D., V. McGowan, and P. H. A. Sneath (ed.). 1980. Approved lists of bacterial names. Int. J. Syst. Bacteriol. 30:225-420. 